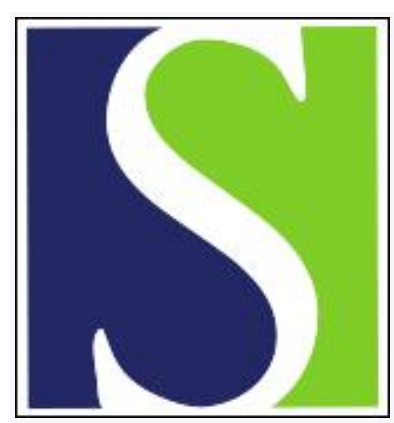

Scand J Work Environ Health 1984;10(1):17-24

https://doi.org/10.5271/sjweh.2368

Issue date: Feb 1984

Cancer incidence among employees in one mineral wool production plant in Denmark.

by Olsen $\mathrm{JH}$, Jensen $\mathrm{OM}$

This article in PubMed: www.ncbi.nlm.nih.gov/pubmed/6547541

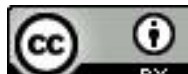




\title{
Cancer incidence among employees in one mineral wool production plant in Denmark
}

\author{
by Jørgen $\mathrm{H}$ Olsen, MD, Ole $M$ Jensen, $M D^{1}$
}

\begin{abstract}
OLSEN JH, JENSEN OM. Cancer incidence among employees in one mineral wool production plant in Denmark. Scand $j$ work environ health 10 (1984) 17-24. The initiating hypothesis of the present study was that exposure to respirable fibers from mineral wool in concentrations seen at the place of production is carcinogenic to the respiratory system. In a test of this hypothesis 5,369 employees in the mineral wool production plant in question were followed from first employment at the plant until day of death or until the end of 1977. The factory started producing mineral wool in 1937 and the Danish Cancer Registry started working on a nationwide scale in 1943; therefore there was a maximum 40 years' duration of employment and 35 years' follow-up in the Cancer Registry. The observed numbers of cancer cases were compared with the expected numbers calculated on the basis of the age-, sex-, and time-specific incidence rates for cancer among the Danish population. Within the study period the Registry received notification of 136 cohort members with one cancer and 4 with two primary cancers, ie, a total of 144 cancer cases was observed against the 133.8 expected. Among workers with 20 or more years from first employment in the plant a significant excess of cancer of the lungs, bladder, and skin was found (observed versus expected cases: 9 vs $4.3,4$ vs 1.6 and 5 vs 2.4 , respectively). This study thus supports the working hypothesis of an association between lung cancer and mineral wool production when the latency period for this type of cancer is taken into consideration.
\end{abstract}

Key terms: bladder cancer, industrial exposures, lung cancer, man-made mineral fibers, occupational health hazards, skin cancer.

The carcinogenicity of asbestos fibers is beyond dispute (7), and some 10 years ago animal studies showed that intrapleural inoculation with fibrous glass causes mesothelioma similar to the effect of asbestos $(20,21,22)$. Since then additional animal evidence has shown that synthetic fibers are capable of producing tumors $(4,10,13,15)$ and that this phenomenon is due to their physical rather than to their chemical properties $(14,18,19)$.

Fibrous glass and fibrous rock are manufactured principally as insulation materials in the form of glass wool and rock wool. In view of the widespread and increasing use of these products - also for replacing asbestos - it is important to determine qualitatively and quantitatively whether they represent a carcinogenic hazard to man. Thus the purpose of the present study was to examine whether exposure to respirable fibers from mineral wool increases the risk of cancer of the respiratory system in humans. This hypothesis was tested in a retrospective study of the incidence of cancer in persons employed in the manufacture of man-made mineral fibers for insulation purposes.

\footnotetext{
1 Danish Cancer Registry, DK-2100 Copenhagen, Denmark.
}

Reprint requests to: Dr JH Olsen, the Danish Cancer Registry, Danish Cancer Society, Landskronagade 66, DK-2100 Copenhagen $\varnothing$, Denmark.

\section{Material and methods}

\section{Study population}

The cohort was formed from the employees of a single Danish factory which started producing mineral wool in 1937. Every person employed at the plant during 1937-1977 was included in the cohort, irrespective of duration of employment. Follow-up was carried out through linkage with central and municipal registries, the name and date of birth (when death before April 1968) and the national personal identification number (when alive in April 1968) being used as identifiers for the employees. As of 31 December 1977,174 persons, ie, $3.36 \%$ of the cohort, could not be traced by this procedure, and they were consequently excluded from further study, as many of them were foreign workers.

The cohort under study then consisted of 5,369 employees. Table 1 shows their characteristics with regard to sex, position in the factory, year of first employment at the factory and the cumulative number of persons ever employed over time. From the table it can be seen that $84 \%$ of the employees was male and that only $25 \%$ of the total cohort was employed at the factory before 1960. Figures 1 and 2 show that the workforce was young at first employment and that duration of employment in the factory was, as a rule, rather short, only $25 \%$ of the em- 
Table 1. Number of employees grouped according to sex, position, and year of first employment in the mineral wool production plant.

\begin{tabular}{|c|c|c|c|c|c|}
\hline \multirow{2}{*}{$\begin{array}{l}\text { Year of first } \\
\text { employment }\end{array}$} & \multicolumn{2}{|c|}{ Manual workers } & \multicolumn{2}{|c|}{ Salaried employees } & \multirow{2}{*}{ Total } \\
\hline & Males & Females & Males & Females & \\
\hline $\begin{array}{l}1937 \\
1938-1942 \\
1943-1947 \\
1948-1952 \\
1953-1957 \\
1958-1962 \\
1963-1967 \\
1968-1972 \\
1973-1977 \\
\end{array}$ & $\begin{array}{r}3 \\
59 \\
81 \\
87 \\
241 \\
825 \\
916 \\
974 \\
1,308 \\
\end{array}$ & $\begin{array}{r}\overline{12} \\
11 \\
13 \\
6 \\
6 \\
14 \\
11 \\
81\end{array}$ & $\begin{array}{r}5 \\
3 \\
3 \\
14 \\
19 \\
46 \\
65 \\
97 \\
186 \\
\end{array}$ & $\begin{array}{r}- \\
-1 \\
3 \\
3 \\
26 \\
65 \\
91 \\
94\end{array}$ & $\begin{array}{r}8 \\
74 \\
96 \\
117 \\
269 \\
903 \\
1,060 \\
1,173 \\
1,669\end{array}$ \\
\hline Total & 4,494 & 154 & 438 & 283 & 5,369 \\
\hline Years at risk ${ }^{a}$ & 45,908 & 1,882 & 3,726 & 2,300 & 53,816 \\
\hline
\end{tabular}

a Because of minor differences in the inclusion criteria, a slight discrepancy exists between these reported years at risk and those reported in the Danish part of the European Man-Made Mineral Fibre Study.

Number of

employees

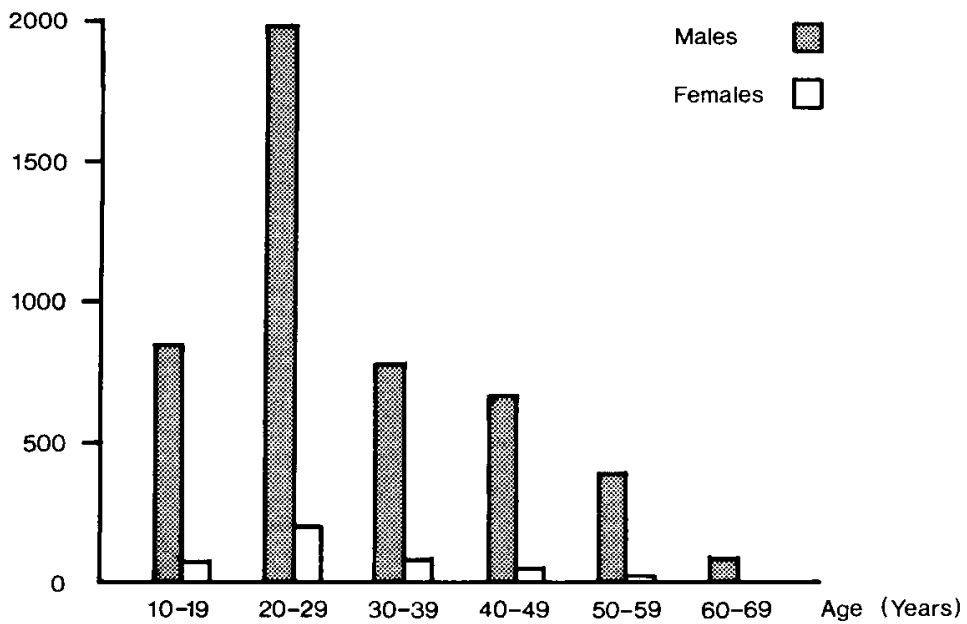

Number of

employees

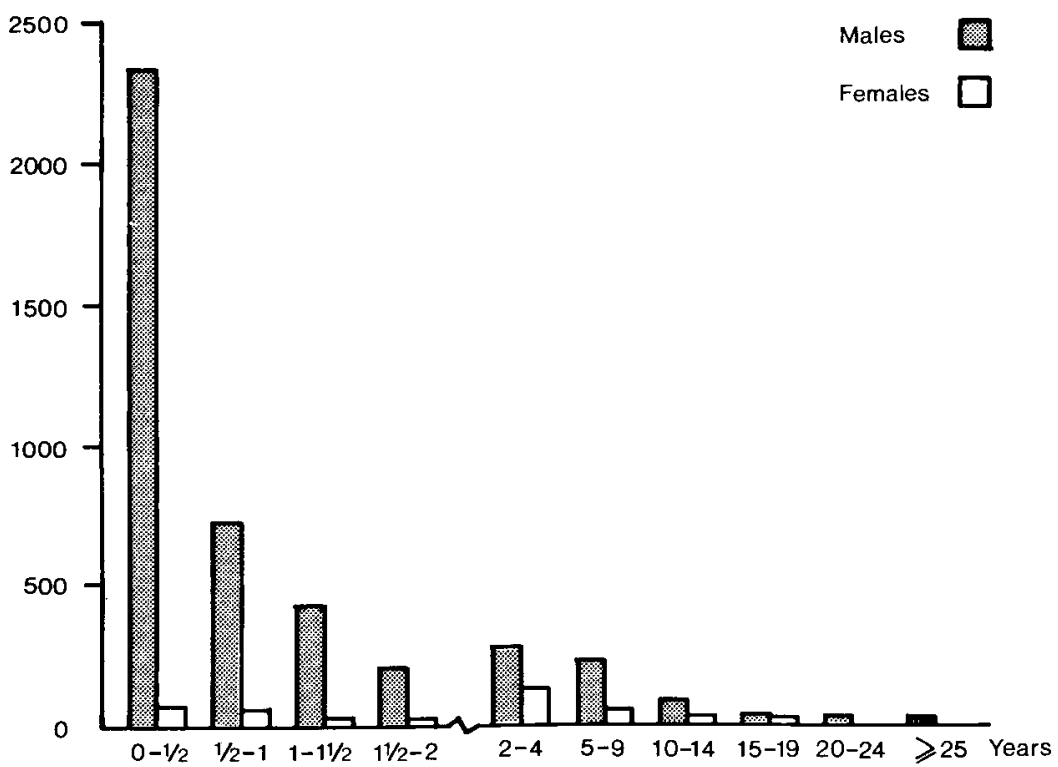

Figure 1. Age distribution for all employees at the time of first employ. ment in the mineral wool production plant.
Figure 2. Number of employees in the mineral wool production plant in 1937-1977 according to duration of employment. 
ployees working at the factory for more than two years.

\section{Exposures}

Mineral fibers. The concentration of respirable fibers in the plant at the time of the study was between 0.1 and 0.001 fibers per millilitre of air with dimensions as shown in table 2 (personal communication from $\mathrm{E}$ Smith, Rockwool International). No previous measurements of airborne fibers were available, but exposure to mineral fibers in the factory is likely to have changed over the years as the production process and hygienic conditions have developed. Since 1949 oil has been used in the production of mineral wool, and from the beginning of the 1950 s also binders. The work conditions before the introduction of oils and binders were imitated in another, but similar, factory, and it was estimated that the concentration of respirable fibers at the production lines in the past was between 9.8 and 26.5 fibers per millimetre of air (personal communication from E Smith, Rockwool International).

Smoking. No information was available on the smoking habits of the persons in the cohort. In order to evaluate the smoking habits of the employees of the mineral wool production plant in comparison to those of the general population, we carried out a survey of the smoking habits at the time of the study. As part of a regular health check-up in 1982 every employee examined was interviewed by the company physician about his or her present and past smoking habits. Questions were identical to those used in 1979 in a survey of smoking habits of the general population in the eastern part of Denmark, where the factory under study is situated.

Other occupational exposures. No knowledge was available on industrial exposures prior to or following employment at the mineral wool production plant, or to other exposures outside the workplace.

\section{Cancer morbidity}

As 1943 was the year when the Danish Cancer Registry started reporting incidence data, the analysis of cancer morbidity was restricted to the period 1943 1977. Members of the cohort were searched for in the files of the national Danish Cancer Registry. All persons alive on 1 April 1968, when national identification numbers were introduced, were identified by means of a computerized record linkage. All other persons were searched for on the basis of date of birth, and the record was given a visual check taking additional account of full name, sex, place of residence and place of birth; thus a previously wellestablished scheme was followed (8). If cancer was registered, the site of cancer and time of diagnosis were obtained directly from the files.

\section{Analysis}

From the first day of employment all persons in the cohort were followed to the day of death, emigration, or the end of 1977. Person-years at risk were calculated (table 1) with a modified life-table method taking account of the ageing of the cohort.

In the calculation of the expected numbers of cancer cases the cancer incidence rates, specific for age (five-year groups), sex and calendar time (quinquennia), for the total Danish population were used, differences in these characteristics of the study and reference populations thus being adjusted indirectly. The expected numbers of cases were compared with the observed ones.

Number of years from first employment, duration of the employment, and specification of cancer site were considered in the analysis. It was presumed that the number of observed cancer cases would follow a Poisson distribution which can be regarded as an approximation to the normal distribution. The test statistic $u$ was therefore calculated as $\mathrm{u}=(\mathrm{O}-\mathrm{E}) / \sqrt{\mathrm{E}}$, where $\mathrm{u}$ is the number of standard deviations with the corresponding $p$-value in the normal distribution, ie, the probability of observing the actual cases of cancer or a number which deviates even more than expected under the assumption of the null hypothesis. The results of both one-sided and two-sided tests of significance have been given, the latter being the more appropriate test strategy with cancer sites for which no strong a priori hypothesis of increased risk exists.

Table 2. Fiber proportions in airborne dust at the production plant, 1982 (12)

\begin{tabular}{|c|c|c|c|c|c|}
\hline \multirow{2}{*}{$\begin{array}{l}\text { Length } \\
\qquad(\mu)\end{array}$} & \multicolumn{5}{|c|}{ Diameter $(\mu)$} \\
\hline & $\begin{array}{c}\leq 0.24 \\
(\%)\end{array}$ & $\begin{array}{c}0.25-0.49 \\
(\%)\end{array}$ & $\begin{array}{c}0.50-0.99 \\
(\%)\end{array}$ & $\begin{array}{c}1.00-2.99 \\
(\%)\end{array}$ & $\geq \underset{(\%)}{3.00^{a}}$ \\
\hline $\begin{array}{l}0-5 \\
5-10 \\
>10\end{array}$ & $\begin{array}{l}2.6 \\
1.1 \\
0.6\end{array}$ & $\begin{array}{l}2.1 \\
3.7 \\
1.8\end{array}$ & $\begin{array}{l}4.2 \\
4.2 \\
8.2\end{array}$ & $\begin{array}{r}1.1 \\
10.9 \\
31.1\end{array}$ & $\begin{array}{r}0.0 \\
0.0 \\
29.0\end{array}$ \\
\hline
\end{tabular}

a Fibers of more than $3 \mu$ in diameter are not respirable. 
Table 3. Number of observed and expected cases of cancer among the male and female employees of the mineral wool production plant, 1943-1977.

\begin{tabular}{|c|c|c|c|c|c|c|}
\hline \multirow{2}{*}{ Site } & \multicolumn{2}{|c|}{ Manual workers } & \multicolumn{2}{|c|}{ Salaried employees } & \multicolumn{2}{|c|}{ All employees } \\
\hline & Observed & Expected & Observed & Expected & Observed & Expected \\
\hline $\begin{array}{l}\text { Buccal cavity } \\
\text { and pharynx }\end{array}$ & 5 & 4.1 & - & 0.3 & 5 & 4.4 \\
\hline $\begin{array}{l}\text { Digestive organs } \\
\text { and peritoneum }\end{array}$ & 39 & 31.0 & 3 & 2.3 & 42 & 33.3 \\
\hline Respiratory system & 28 & 26.4 & 1 & 1.7 & 29 & 28.1 \\
\hline Breast & 2 & 1.8 & 2 & 0.9 & 4 & 2.7 \\
\hline Genital organs & 12 & 13.8 & 1 & 1.7 & 13 & 15.5 \\
\hline Urinary system & 16 & 13.1 & 1 & 0.9 & 17 & 14.0 \\
\hline Skin & 14 & 14.4 & 3 & 1.4 & 17 & 15.8 \\
\hline Brain and & 1 & 4.8 & - & 0.5 & 1 & 5.3 \\
\hline $\begin{array}{l}\text { Lymphatic and } \\
\text { hemotopoietic tissues }\end{array}$ & 9 & 8.8 & - & 0.8 & 9 & 9.6 \\
\hline $\begin{array}{l}\text { Other organs } \\
\text { including metastases }\end{array}$ & 6 & 4.7 & 1 & 0.4 & 7 & 5.1 \\
\hline Total & 132 & 122.9 & 12 & 10.9 & 144 & 133.8 \\
\hline
\end{tabular}

Table 4. Number of observed $(O)$ and expected $(E)$ cases of cancer reported for selected sites among the workers of the mineral wool production plant, 1943-1977.

\begin{tabular}{|c|c|c|c|c|c|c|c|c|}
\hline \multirow{3}{*}{ Site } & \multicolumn{8}{|c|}{ Years elapsed from first employment } \\
\hline & \multicolumn{2}{|c|}{$0-9$} & \multicolumn{2}{|c|}{$10-19$} & \multicolumn{2}{|c|}{$\geq 20$} & \multicolumn{2}{|c|}{ Total } \\
\hline & Observed & Expected & Observed & Expected & Observed & Expected & Observed & Expected \\
\hline $\begin{array}{l}\text { Digestive organs } \\
\text { and peritoneum }\end{array}$ & 21 & $13.8^{\mathrm{a}}$ & 15 & 11.3 & 3 & 5.9 & 39 & 31.0 \\
\hline $\begin{array}{l}\text { Respiratory } \\
\text { system } \\
\text { Larynx } \\
\text { Lungs and }\end{array}$ & $\begin{array}{r}12 \\
3\end{array}$ & $\begin{array}{r}11.9 \\
1.0\end{array}$ & 7 & $\begin{array}{l}9.7 \\
0.7\end{array}$ & $\stackrel{9}{-}$ & $\begin{array}{l}4.8^{b} \\
0.3^{b}\end{array}$ & $\begin{array}{r}28 \\
3\end{array}$ & $\begin{array}{r}26.4 \\
2.0\end{array}$ \\
\hline pleurae & 8 & 10.2 & 7 & 8.4 & 9 & $4.3^{c}$ & 24 & 22.9 \\
\hline $\begin{array}{l}\text { Urinary system } \\
\text { Kidney } \\
\text { Bladder }\end{array}$ & $\begin{array}{l}9 \\
3 \\
6\end{array}$ & $\begin{array}{l}5.9 \\
1.8 \\
4.0\end{array}$ & $\begin{array}{l}3 \\
1 \\
2\end{array}$ & $\begin{array}{l}4.8 \\
1.4 \\
3.3\end{array}$ & $\frac{4}{4}$ & $\begin{array}{l}2.4 \\
0.7 \\
1.6^{\mathrm{d}}\end{array}$ & $\begin{array}{r}16 \\
4 \\
12\end{array}$ & $\begin{array}{r}13.1 \\
3.9 \\
8.9\end{array}$ \\
\hline Skin & 4 & 6.8 & 5 & 5.2 & 5 & $2.4^{e}$ & 14 & 14.4 \\
\hline Other Organs & 17 & 19.3 & 13 & 12.6 & 5 & 6.3 & 35 & 38.0 \\
\hline Total & 63 & 57.7 & 43 & 43.6 & 26 & 21.8 & 132 & 129.9 \\
\hline
\end{tabular}

a $\mathrm{O} / \mathrm{E}=1.5, \mathrm{p}=0.03$ (one-sided test); $\mathrm{p}=0.05$ (two-sided).

b $\mathrm{O} / \mathrm{E}=1.9, \mathrm{p}=0.03$ (one-sided test); $\mathrm{p}=0.06$ (two-sided).

c $O / E=2.1, p=0.01$ (One-sided test); $p=0.02$ (two-sided).

$d \mathrm{O} / \mathrm{E}=2.5, \mathrm{p}=0.03$ (one-sided test); $\mathrm{p}=0.06$ (two-sided)

$O \mathrm{O} / \mathrm{E}=2.1, \mathrm{p}=0.05$ (one-sided test); $\mathrm{p}=0.09$ (two-sided).

Table 5. Number of observed $(\mathrm{O})$ and expected $(\mathrm{E})$ cases of lung cancer and all cancers occurring 20 years or more since first employment in different subgroups of the employees of the mineral wool production plant, 1943-1977.

\begin{tabular}{|c|c|c|c|c|}
\hline \multirow{2}{*}{ Sub-group of employees } & \multicolumn{2}{|c|}{ Lung cancer } & \multicolumn{2}{|c|}{ All cancers } \\
\hline & Observed & Expected & Observed & Expected \\
\hline $\begin{array}{l}\text { Male manual workers } \\
\text { Female manual workers } \\
\text { Male salaried employees } \\
\text { Female salaried employees }\end{array}$ & $\begin{array}{r}8 \\
1 \\
1 \\
-\end{array}$ & $\begin{array}{l}4.1^{\mathrm{a}} \\
0.2 \\
0.5 \\
0.0\end{array}$ & $\begin{array}{r}126 \\
6 \\
8 \\
4\end{array}$ & $\begin{array}{r}116.0 \\
6.8 \\
7.4 \\
3.5\end{array}$ \\
\hline All employees & 10 & $4.8^{b}$ & 144 & 133.7 \\
\hline
\end{tabular}

a $O / E=2.0, p=0.03$ (one-sided test) $p=0.05$ (two-sided).

b $\mathrm{O} / \mathrm{E}=2.1, \mathrm{p}=0.01$ (one-sided test); $\mathrm{p}=0.02$ (two-sided). 
Table 6. Number of observed and expected cases of cancer occurring among the workers, grouped according to duration of employment in the mineral wool production plant.

\begin{tabular}{|c|c|c|c|c|c|c|c|c|c|c|}
\hline \multirow{3}{*}{ Organ $^{a}$} & \multicolumn{10}{|c|}{ Duration of employment (years) } \\
\hline & \multicolumn{2}{|c|}{$<1$} & \multicolumn{2}{|c|}{1} & \multicolumn{2}{|c|}{$2-4$} & \multicolumn{2}{|c|}{$5-9$} & \multicolumn{2}{|c|}{$10-39$} \\
\hline & Observed & Expected & Observed & Expected & Observed & Expected & Observed & Expected & Observed & Expected \\
\hline $\begin{array}{l}\text { Lungs } \\
\text { Bladder } \\
\text { Skin } \\
\end{array}$ & $\begin{array}{l}4 \\
2 \\
3 \\
\end{array}$ & $\begin{array}{l}2.0 \\
0.8 \\
1.2 \\
\end{array}$ & $\frac{3}{-}$ & $\begin{array}{l}0.4 \\
0.2 \\
0.3 \\
\end{array}$ & $\frac{1}{2}$ & $\begin{array}{l}0.5 \\
0.2 \\
0.3 \\
\end{array}$ & $\bar{z}$ & $\begin{array}{l}0.3 \\
0.1 \\
0.2 \\
\end{array}$ & $\begin{array}{r}1 \\
2 \\
- \\
\end{array}$ & $\begin{array}{l}0.9 \\
0.4 \\
0.5 \\
\end{array}$ \\
\hline Total & 9 & 4.0 & 3 & 0.9 & 3 & 1.0 & - & 0.6 & 3 & 1.8 \\
\hline
\end{tabular}

a Only cancer cases diagnosed 20 years or more from first employment are included.

Table 7. Age- and sex-standardized smoking habits of the workers in the mineral wool production plant in 1982 in comparison to those of the general population surveyed in 1979 .

\begin{tabular}{|c|c|c|c|c|c|c|}
\hline & \multicolumn{3}{|c|}{ Smokers } & \multicolumn{3}{|c|}{ Heavy smokers } \\
\hline & $\begin{array}{l}\text { Male } \\
(\%)\end{array}$ & $\begin{array}{c}\text { Female } \\
(\%)\end{array}$ & $\begin{array}{c}\text { All } \\
(\%)\end{array}$ & $\begin{array}{c}\text { Male } \\
(\%)\end{array}$ & $\underset{(\%)}{\text { Female }}$ & $\begin{array}{l}\text { All } \\
(\%)\end{array}$ \\
\hline $\begin{array}{l}\text { Workers } \\
\text { General population }\end{array}$ & $\begin{array}{l}69 \\
59\end{array}$ & $\begin{array}{l}72 \\
46\end{array}$ & $\begin{array}{l}69 \\
59\end{array}$ & $\begin{array}{l}37 \\
43\end{array}$ & $\begin{array}{r}6 \\
18\end{array}$ & $\begin{array}{l}35 \\
42\end{array}$ \\
\hline Difference & +10 & +26 & +10 & -6 & -12 & -7 \\
\hline
\end{tabular}

a The figures for female workers are based on 18 workers only.

\section{Results}

The observed and expected numbers of cancer cases among the 5,369 identified employees at the mineral wool production plant are given in table 3 according to site. During the study period 136 persons were found with one cancer and four persons with two primary cancers, ie, a total of 144 cancer cases were observed. None of the organ systems showed a statistically significant excess of observed cases in comparison to the expected numbers.

The manual workers formed the only group of employees providing a sufficient number of cases for a detailed analysis by specific cancer sites and time since first employment. Table 4 shows the observed and expected numbers of cancer cases for selected sites during the periods $0-9$ years, $10-19$ years, and $\geq 20$ years from first employment at the mineral wool production plant. Cancer of the digestive organs was increased during the first 10 years since first employment. In the subgroup of workers with 20 years or more having elapsed from first employment at the factory, more cases than expected were found for the respiratory system, the urinary system, and the skin, in particular cancer of the lung and cancer of the bladder (table 4).

One case of pleural mesothelioma was observed in a person 13 years after first employment in the factory.

The observed and expected numbers of cases of lung cancer, as well as cancer of all sites, are given in table 5 for all four categories of employees. In the $\geq 20$-year subgroup of the total cohort (males and females) the observed : expected ratio for lung cancer was 2.1 (10 observed, 4.8 expected), a figure significantly in excess of $1.0(p=0.009)$. The pattern of increase seems to be similar for the two male groups, but, except for the male manual workers, the numbers of lung cancer cases were too small to allow for meaningful evaluation.

Information on exposure within the plant was incomplete or missing. Using the duration of employment as an indicator of the degree of exposure, we examined the data for a dose-response relationship for all the workers at the factory (table 6) for the sites showing an increased rate 20 years or more after first employment. No relationship between duration of employment and cancer risk emerged.

Table 7 shows the smoking habits of the workers employed at the mineral wool production plant in 1982 , ie, the time of the study. For comparison the smoking habits of the general population in the eastern part of Denmark are given for 1979 (according to the unpublished results of B Roed-Petersen) after standardization for differences in age and sex. There were $10 \%$ more smokers among the rockwool workers than among the general population, but $7 \%$ less heavy smokers among the former.

\section{Discussion}

In this study of cancer morbidity among the employees of a single mineral wool production plant in Denmark no increased risk of cancer was found for all cancer cases together or for cancer cases grouped 
according to site of appearance when the cohort was analyzed as a whole. However, if one considers the group of persons among whom the highest risk would be expected to emerge a priori, ie, workers for whom 20 years had elapsed since first employment at the plant, a twofold increase in risk of cancer of the lung, bladder, and skin was found (table 4). Although the observed numbers of cases on which these risk estimates were based were small, the deviations from unity were statistically significant.

In a comprehensive study like the present one the possibility of chance variation could explain the excess of skin and bladder cancer due to the many comparisons undertaken. It seems reasonable however to consider a possible association with the work environment and to include these cancers in future studies of the mineral wool production industry.

The major objective of this study was to evaluate whether an association exists between exposure to mineral wool - especially fibers - and cancer of the respiratory tract. The increased risk among workers 20 or more years after first employment is in line with this hypothesis, but a number of potential errors must be considered.

The group of people under investigation was formed on the basis of existing documentation in the factory, and without knowledge of later cancer development. The follow-up of the group was almost complete $(96.6 \%)$, and the information about incident cancer cases was obtained from an independent source - the Danish Cancer Registry - without knowledge of the person's occupation within the plant. Thus the study is unbiased with regard to the registration of cancer incidence among the factory's personnel.

On the other hand, in a retrospective cohort study, it is difficult to evaluate to what degree confounding factors have influenced the risk estimates. In the study of lung cancer in particular the role of tobacco smoking must be considered, as well as the possible influence of other occupational exposures. As in most retrospective cohort studies information on such factors was missing and attempts to control or assess such confounding could only be indirect.

Several different approaches were used to determine whether the use of rates for all of Denmark as the reference could explain the increased lung cancer risk among the mineral wool workers, as it was unknown to what degree the total Danish population differed from our study population with respect to other occupational exposures and life-style factors in particular. First, an alternative computation of the expected number of cancer cases was undertaken by using cancer rates for a population composed like the cohort under study with regard to place of residence, a factor indicative of both smoking and occupation $(3,9)$. This additional standardization for place of residence resulted in an overall $8.3 \%$ decrease in the expected number of lung cancer cases, a figure cor- responding to a $9 \%$ increase in the calculated observed : expected ratios (12).

Second, the standardized mortality ratio for cancer of the respiratory system is 1.13 for unskilled male workers in Denmark in comparison with all males (11); this value contrasts with the finding of a standardized incidence ratio of $\mathbf{1 . 9 5}$ for male workers in the present study (table 5).

Third, we surveyed the smoking habits of presently employed workers at the mineral wool production plant and compared them with those of the general population of the eastern part of Denmark, where the plant is located, assuming that the differences observed represented different smoking habits in the study population and the reference population. It is unlikely that the finding of $10 \%$ more smokers in the cohort, but $7 \%$ less heavy smokers, could explain the observed excess of lung and bladder cancer among the factory workers. Thus, if the relative risk of lung cancer estimated by Doll \& Peto (5), ie, 1 for nonsmokers, 10 for moderate smokers (less than 15 cigarettes/d) and 20 for heavy smokers (more than 15 cigarettes/d), are applicable also to the present material, then it can be calculated $(1,2)$ that the differences in smoking habits seen in the present investigation would lead to a relative risk of 1.04 among rock wool workers when compared with the general population. In addition the increased risk of lung cancer 20 years or more after first employment at the factory seems incompatible with an effect of tobacco, since an elevated risk caused by this latter risk factor would appear throughout the observation period independently of the date of entry into the mineral wool production plant. Finally, there has been no exposure to asbestos in the factory except for underwater sawing of prefabricated building material containing asbestos during the period 1967-1980. To our knowledge no asbestos-consuming industry has been located near the plant or in the area from which the plant draws its labor.

In conclusion, it is unlikely then that the association between employment in the plant producing man-made mineral fibers and the risk of lung cancer development 20 or more years after first employment could be ascribed to bias in cancer ascertainment or to factors such as tobacco smoking or other occupational exposures unrelated to the hypotheses under study.

A similar American study, comprising nearly 17,000 employees in the mineral wool industry in the United States, found the mortality from respiratory tract cancer increased, but only in that part of the cohort which was involved in rock wool (standardized mortality ratio $=160$ ), rather than glass wool, production (6). The authors could not exclude asbestos as contributing to this increased risk. The increased mortality was associated neither with the length of time since first employment nor with the estimated degree of exposure to fibers during work. 
In a similar collaborative European investigation (of which the Danish cohort is a part) the standardized mortality ratio for cancer of the trachea, bronchus, and lung among the group of rock wool workers was 91,124 , and 195 for $0-19$ years, $20-29$ years, and 30 years or more from the date of first employment in the factory, respectively (17). Neither in this study is the increased mortality related to the extent of estimated fiber exposure. In a review of the epidemiologic evidence of respiratory cancer among workers exposed to man-made mineral fibers it is stated that five studies out of nine present some association between respiratory cancer with work involving mineral fibers. These five studies include the two largest cohort studies already mentioned. In neither study and for none of the production types, was any relation of respiratory cancer to exposure duration and exposure intensity found (16).

In conclusion the results of the present study support the hypothesis of a relationship between occupation in the mineral wool production industry and cancer of the lung; the suspicion raised by this study, of an association between occupation in this industry and cancer of the skin and bladder, should be investigated further. In this connection it may be profitable to consider exposure to substances other than fibers since, from the period around 1950 , oils and binders have been added to the mineral wool in considerable quantities.

The increased cancer risk that has emerged from this study was presumably initiated before 1960 and therefore relates to the environmental conditions, including dust levels, prevailing in the factory from the beginning of production up to around 1960. This factor points to a need for the continued follow-up and investigation of workers employed in the mineral wool industry to investigate possible risks associated with exposure to present-day airborne fiber concentrations. The lack of a dose-response relationship also requires additional follow-up to be better determined, as it is of importance for establishing evidence of causality. Further investigations are thus of paramount importance in view of the widespread use of mineral wool for insulation purposes in most kinds of building construction today.

\section{Acknowledgments}

The authors are grateful to the management of Rockwool International, especially to ED Smith and Dr E Rasmussen, for the cooperation received and to Mr HS Jensen of the Danish Cancer Registry for his valuable assistance. Ms $\AA$ Larsen and Mr N Christense, the Danish Cancer Registry, assisted with the data collection and analysis.

This study was supported by the International Agency for Research on Cancer (RA/78/020). Dr J
Olsen was supported by the Environmental Cancer Program of the Danish Cancer Society (M 1/81).

\section{References}

1. Axelson $O$. Aspects on confounding in occupational health epidemiology. Scand $\mathrm{j}$ work environ health 4 (1978) 85-89.

2. Borch-Johnsen K. Byliv og lungecancer: En kvantitativ og kvalitativ analyse af den urbane faktor. Ugeskr læger 144 (1982) 1713-1718.

3. Danmarks Statistik. Registerfolketællingen 1. juli 1976. Vol II. København 1979.

4. Davis JMG. Pathological aspects of the injection of glass fibre into the pleural and peritoneal cavities of rats and mice. In: National Institute for Occupational Safety and Health. Occupational exposure to fibrous glass. Washington DC 1976, pp 41-149. (DHEW publication no NIOSH 76-151).

5. Doll $\mathbf{R}$, Peto $\mathbf{R}$. Mortality in relation to smoking: 20 years' observations on male British doctors. $\mathrm{Br}$ med $\mathrm{j}$ 2 (1976) 1525-1536.

6. Enterline PE, March GM. Mortality studies in USA. In: WHO/EURO biological effects of man-made mineral fibres: Occupational health conference, Copenhagen, 20-22 April 1982: Proceedings of the conference. World Health Organization, Copenhagen (in press).

7. International Agency for Research on Cancer. Asbestos. Lyon 1973. (IARC monographs on evaluation of the carcinogenic risk of chemicals to man, volume 14).

8. Jensen OM. Cancer morbidity and causes of death among Danish brewery workers. International Agency for Research on Cancer, Lyon 1980. (IARC non-serial publication).

9. Komiteen til undersøgelse af den danske befolknings sundhedstilstand. Morbiditetsundersøgelsen af 1950: Sygdomsundersøgelsen i Danmark 1951-1954. Munksgaard, København 1960.

10. Lafuma J, Morin M, Poncy JL, Masse R, Hirsch A, Bignon J, Monchaux G. Mesothelioma induced by intrapleural injection of different types of fibres in rats: Synergistic effect of other carcinogens. In: Wagner JC, ed. Biological effects of mineral fibres. Volume 1. International Agency for Research on Cancer, Lyon 1980, pp 311-320. (IARC scientific publications no 30).

11. Lynge E. Dødelighed og erhverv 1970-75. Danmarks Statistik, København 1979. (Statistiske undersøgelser nr 37).

12. Olsen $\mathbf{J H}$, Jensen $\mathrm{OM}$, Rasmussen E. Mineraluldsproduktion og cancer. Cancerregisteret, København 1983. (Rapport 1).

13. Pott F. Some aspects on the dosimentry of the carcinogenic potency of asbestos and other fibrous dusts. Staub Reinhalt Luft 38 (1938) 486-490.

14. Pott F, Friedrichs K-H, Huth F. Ergebnisse aus Tierversuchen zu kanzerogenen Wirkung faserförmiger Stäube und Ihre Deutung im Hinblick auf die Tumorentstehung beim Menschen. Zbl Bakt Hyg I Abt Orig B 162 (1976) 467-505.

15. Pott F, Huth F, Spurny K. Tumor induction after intraperitoneal injection of fibrous dust. In: Wagner JC, ed. Biological effects of mineral fibres. Volume 1. International Agency for Research on Cancer, Lyon 1980 , pp $337-342$. (IARC scientific publications no 30).

16. Saracci R, Simonato L. Man-made vitreous fibers and workers' health: An overview of the epidemiologic evidence. Scand j work environ health 8 (1982) 234-242.

17. Saracci R, Simonato L, Acheson ED, Andersen Ȧ, 
Bertazzi PA, Charnay N, Claude J, Esteve J, FrentzelBeyme RR, Gardner M, Jensen O, Maasing R, Olsen J, Teppo L, Zacchetti C, Westerholm P. The IARC mortality and cancer incidence study of man-made (vitreous) fibre (MMM(v)F) production workers in seven European countries. In: World Health Organization. WHO/EURO biological effects of man-made mineral fibres: Occupational health conference, Copenhagen, 20-22 April 1982: Proceedings of the conference. Copenhagen (in press).

18. Smith WE, Hubert DD, Sobel HJ. Dimensions of fibres in relation to biological activity. In: Wagner JC, ed. Biological effects of mineral fibres. Volume 1. International Agency for Research on Cancer, Lyon 1980, pp 357-360. (IARC scientific publications no 30).

19. Stanton MF, Layard M, Tegeris A, Miller E, May M, Kent E. Carcinogenicity of fibrous glass: Pleural response in rat in relation to fibre dimensions. $\mathrm{J}$ natl cancer inst 58 (1977) 587-603.
20. Stanton MF, Wrench C. Mechanisms of mesothelioma in rats after inoculation with asbestos and other materials. Br j cancer 28 (1973) 173-185.

21. Wagner JC, Berry G, Skidmore JW. Studies of the carcinogenic effects of fibre glass of different diameters following intrapleural inoculation in experimental animals. In: National Institute for Occupational Safety and Health. Proceedings of the NIOSH symposium on occupational exposure to fibrous glass, University of Maryland, June 26-27, 1974. Washington, DC 1976. (DHEW publication no 76-151).

22. Wagner JC, Berry G, Timbrell V. Mesotheliomata in rats after inoculation with asbestos and other materials. $\mathrm{Br} \mathrm{j}$ cancer 28 (1973) 173-185.

Received for publication: 9 September 1983 